\title{
Immature Plasma Cell to Lymphocyte Ratio Measurement
}

National Cancer Institute

\section{Source}

National Cancer Institute. Immature Plasma Cell to Lymphocyte Ratio Measurement.

NCI Thesaurus. Code C96680.

The determination of the ratio of immature plasma cells compared to total lymphocytes present in a sample. The measurement may be expressed as a ratio or percentage. 